\title{
Word Selection in Teaching Arabic Vocabulary for Lower Secondary Level
}

\author{
Aisah Hasmam ${ }^{1}$ Nik Mohd Rahimi², Nik Farhan Mustapha ${ }^{3}$, \\ Mohd Yusri Kamarudin'1 \\ ${ }^{1}$ Ministry of Education, Putrajaya, Malaysia \\ ${ }^{2}$ Faculty of Education, National University of Malaysia, Bangi, Malaysia \\ ${ }^{3}$ University Putra Malaysia, Serdang, Malaysia \\ Email: aisahhasmamsp2@gmail.com,nik@ukm.edu.my, farhan@upm.edu.my, yusriqanun@yahoo.com
}

Received 28 January 2016; accepted 5 March 2016; published 8 March 2016

Copyright (C) 2016 by authors and Scientific Research Publishing Inc.

This work is licensed under the Creative Commons Attribution International License (CC BY).

http://creativecommons.org/licenses/by/4.0/

(c) (i) Open Access

\begin{abstract}
Selecting words for teaching vocabulary is an important part of the teaching and learning of a language. The study aims to explore teacher approach and practice in choosing words for teaching Arabic language at the Lower Secondary Level. A qualitative single case study is used to investigate a phenomenon in the context of the actual situation. Data collection process involves interviews, classroom observation, video recording and analysis of relevant documents. A purposive sampling method is carried out for selection of participants. The findings indicate that the approach used in selecting vocabulary can be divided into five categories: i) priority; ii) frequency; iii) teaching ability; iv) coverage; and v) familiarity. In other words, it is suggested that in facilitating student comprehension and retention of target words, various criteria are considered by a teacher before choosing the teaching approach. The study also provides guidelines for choosing words to teach especially for Arabic teachers in the Lower Secondary Level.
\end{abstract}

\section{Keywords}

Teaching Vocabulary, Teacher Approach, Arabic Language Teachers

\section{Introduction}

In the teaching of a second language, vocabulary selection is crucial and needs to be emphasized (Nation, 2013; Silverman \& Hartranft, 2015). This is because a careful selection of appropriate words by the teacher can facilitate the learners to understand, recall and use the vocabulary effectively (Tacimah, 1989). According to Mohamad (2015), a language teacher has to consider the level, the usage and needs of students while selecting voca- 
bulary which forms the integral part of language learning and teaching (Benjamin \& Crow, 2010) and hence it calls for careful consideration from the teacher (Razak, 2014).

Research has shown that vocabulary selection requires justification and consideration on the teacher's part without putting reliance on a particular criterion only. A study by Nation \& Beglar (2007) indicates that a teaching approach that does not emphasize particular vocabulary to be learnt may not facilitate the weak students' performance. Mohamad (2001) also discovers that students' recall of Arabic vocabulary deteriorates within a week if only a reading technique is used without emphasizing selected vocabulary to be memorized. In addition, a study by Rahimi et al. (2014) also shows that semantic clustering is less facilitative compared to free clustering technique in helping students remember vocabulary they have learnt.

However, research has shown that vocabulary selected from one of the criteria proposed by language experts is able to facilitate students to comprehend, recall and master the vocabulary learnt. Previous studies have investigated recall strategy based on free clustering technique (Hussin, 2011), teaching and learning of vocabulary guided by selected Arabic vocabulary (Kadir, 2011), vocabulary teaching based on Malay vocabulary immersion using the "MUKADDAM" module (Chik, 2004) and learning of text based on learners' own experiences (Abdullah \& Sivaganga, 2010).

In the context of teaching Arabic language in Malaysia specifically to lower secondary students, there are two main sources available for a teacher in choosing the vocabulary to be taught; the Arabic language syllabus based on the Integrated Secondary School Curriculum (KBSM) and the Arabic text books. Following the Arabic language syllabus (KBSM), secondary students are expected to learn 1500 words and are able to use them in various situations (Curriculum Development Department, 2007). To facilitate the teacher in the teaching and learning process, these 1500 words are listed following particular fields or themes (محور). It is these lists which must be focused on during teaching while there are 100 additional words to be taught according to suitability. However, teaching vocabulary is not limited to these words alone as teachers have the freedom to include vocabulary deemed appropriate and relevant to the themes outlined in the syllabus (Curriculum Development Department, 2007). The vocabulary in the KBSM Arabic language textbook is presented in sentences or texts related to themes outlined in the curriculum specifications. For example, a reading text on education may contain vocabulary associated with school days while a folklore-themed text may contain vocabulary related to the famous stories of the deer and crocodiles (Seman, Abdullah, Othman, \& Hasmadi, 2009). Hence, it is emphasized again the important role played by Arabic language teachers in deciding vocabulary selection to be taught from the syllabus, textbook or supplementary reference based on specific theme or objective.

\section{Problem Statement}

Tacimah (2001) stresses the importance for an Arabic language teacher to carefully select words to teach to learners but there is evidence suggesting a lack of emphasis on the lexical aspect (Mezah \& Mohamad, 2013) that it affects the teaching strategy used by teachers (Samah, Hamid, Sha'ari, \& Sha'ari, 2013). Hussin (2011) further states that the situation is probably due to some Arabic teachers' assumptions that general approach to language learning has already included vocabulary learning without the need for specific or direct teaching of vocabulary. Even Nation (2013) proposes that explicit teaching of vocabulary in a second language teaching is one of beneficial strategies that must be emphasized. One of the criteria for explicit vocabulary teaching involves teaching specific words based on the students' level of learning and not simply carried out at random or based on teachers' fancies without reference to particular guidelines (Razak, 2014).

Besides, the readability aspect also needs consideration before teaching specific vocabulary. A study by Mohamad (2015) discovered that the vocabulary in a textbook for Year 1 students in Malaysia did not live up to the criteria proposed by linguists. Another study on content validity of Arabic language textbook for secondary school students showed readability was at low level (Ghani, 2011). This calls for improvement at all levels in the process of selecting vocabulary for Arabic teaching and learning.

In addition, in a study on corpus analysis of school children textbook by Nagy \& Anderson (1984), there are 88,000 different words identified and on average children need to learn 7000 words every year. On the other hand, a study by Ramli \& Mohamad (2014) reveals that there are 6219 Arabic words to be learnt by primary school students. Another corpus analysis conducted on Arabic language textbook used for the Malaysian Higher Religious School Certificate (STAM) using Wordsmith 6.0, has discovered a total of 13,2000 words for students to learn from three texts; one Fiqh and two Hadiths (Razak, 2014). The findings discussed above show the need for students to study thousands of words throughout their studies at all levels. Hence it is imperative for Arabic 
language instructors to exercise wise judgment in choosing vocabulary for the students to learn so it facilitates recall of the vocabulary and mastery of the Arabic language (Tacimah, 2001). Therefore this study is carried out to addresses the issue in-depth and explore the vocabulary selection criteria practised by the Arabic language teachers especially at the lower secondary level.

\section{Literature Review}

Basically the criteria in choosing words to teach put forward by both the western and Arab linguistic and psycho-linguistic scholars share similar principles but differ in elaboration and discussion. In this section, the focus will be elaborated and any differences in point of view will be treated as complementary. The study was conducted in the context of selecting vocabulary for Arabic as a second language in Malaysia and based on a study on the teaching and learning of Arabic by non-native speakers in the South East, Chik (1994) summarised vocabulary selection process must be guided by two domains; the linguistic and psycho-linguistic domains.

The first is the linguistic domain in which words chosen are based on i) frequency (التواتر) of usage or repetition discovered in learning texts, sentences and from students' daily communication, and ii) range (الترازع) which refers to the wide coverage of usage of the words among the Arab nations and such words are normally found in Arabic dictionaries or encyclopedias.

The second is the psycho-linguistic domain in which words chosen are based on, i) their varied meanings as the vocabulary is applicable in various sentence contexts despite differences in meanings hence it can easily be retrieved by students for verbal response or in writing; ii) familiarity (الألفة) in which the vocabulary selected must be familiar and used widely in daily conversation; and iii) priority (الأهمية) as the vocabulary selection follows the priority set by the learning objectives stipulated, deemed vital to be mastered by the students and is relevant to particular themes without neglecting other words with general functions and needs. For example الطالب - ذهب - درس is often used in the examination rubric for simple sentence construction. Hence Arabic language teachers need to select and introduce these words from the start in order to familiarise their students with the vocabulary for sentence construction or daily communication.

Besides Tacimah (1989) also adds that the following criteria are necessary in teaching vocabulary for Arabic as a second language: i) familiarity as the words are widely used in daily conversation; ii) coverage as the words should have a wide coverage in terms of usage; and iii) using the Standard Arabic that reflects its "Arabness", using fully the standard or "fushah" Arabic rather than adopting loan words.

On the other hand, Abd Bari (2011) also proposes supplementary criteria which include: i) similarity (التشابه) in which the vocabulary selected should contain similar elements with the learners' first language or other foreign languages with some consideration for "absorbed" or loan words from another language (for example, the word "chair" in Malay language is pronounced as كرسي in Arabic); and ii) coverage (الثمول) in which the vocabulary has a wide usage (for instance the word بيت is more widely used in various contexts, among otherscompared to the word منزالعنكبوت - بيتنا - بيتالمالبيتالة connotative meanings (العشتر كاللفظي). Another example, is the word (العزل) that refers to 'eyes' but it can also refer to "spies". The last criterion by Abd Bari (2011) is the defining power (القوةالتعريفية) of the vocabulary in regard to the words being used to explain meanings of others even if the vocabulary is restricted to certain topics. For example, the word "independence" may indirectly teach students related concepts of "celebration”, "parade”, "colonialism" and so on.

The western scholars have also put forward their criteria for vocabulary selection. For example, Biemiller (2010) and Nation (2013) proposes for teachers to select words to teach based on the learning objectives, teachers' consideration and preference as long as they are compatible with the learners' needs and levels. Nation (2013) goes further by stating the selection should also be based on new and learned vocabulary, both of which are taught separately or from texts.

On a similar topic, Benjamin \& Crow (2010) suggest frequency as the main criterion besides using the common list usually prepared by curriculum designers (The Generic Academic Vocabulary List) or choosing words based on themes or specific subjects. In other words, in teaching vocabulary teachers are encouraged to be selective and use a variety of teaching resources.

Another criteria list for vocabulary teaching is suggested by Silverman \& Hartranft (2015) based on: i) how important the words are for the students to learn; ii) repetitive words in learning text; iii) words related to theme and content of subject; and iv) wide usage of words in various fields for students' comprehension of text in different context. The criteria discussed will be used as guidelines in the present study that seeks to explore the real 
context of vocabulary selection for teaching Arabic language at lower secondary level in Malaysia.

\section{The Study}

The purpose of this study is to explore and obtain a deeper understanding on teacher strategies and practices in selecting words for Arabic Language instruction for lower secondary level with the emphasis placed on the process rather than the outcomes. In the course of the study, the researcher explored and documented how Nuraini, a creative teacher provided word selection strategies for Arabic vocabulary instruction. Selection of words in this study refers to selection of words based on the Arabic language syllabus from the Integrated Secondary School Curriculum (KBSM) and the Arabic textbooks for form one students.

\section{Methods}

This qualitative case-study or single-site case design (Yin, 2011) focuses on the subject with the criteria and characteristics to be studied to give an overview of the phenomenon (Merriam, 2009). A case-study approach was employed in this study in order to carry out a more comprehensive investigation of a particular event from the view of all the participants (Yin, 2011). Furthermore, it also offered detailed, in-depth data collection involving multiple sources of information and reported a case description and case-based themes (Creswell, 2014). In this case, it refers to the teacher's strategies and practices in selecting words for her Arabic class. Thus, a school was selected as a site to conduct this study with the researcher as a non-participant observer throughout the study to evade interference in teaching during the actual lessons (Merriam, 2009).

Sources of data comprised four observations, field notes, teacher interviews, and document analysis. Following the lessons, Ustazah Nuraini was interviewed based on an interview protocol to clarify her strategies and practices in her selection of words for the Arabic language instruction. Each interview was audio-recorded and then transcribed verbatim. Video recordings were studied simultaneously by the researcher to find out particular prevalence of teacher strategies.

\section{Setting and Participants}

The study took place in an Arabic language classroom at a religious secondary school located in Nilai district, about $35 \mathrm{~km}$ from the Seremban city. The participant is a female experienced language teacher who received a recognition as a creative teacher from the state education department of Negeri Sembilan. The respondent, known as Nuraini has taught Arabic language for almost 15 years and has wide exposure to the subject matter especially in vocabulary instruction.

\section{Results and Discussion}

Selection of words refers to the vocabulary selected by the teacher based on certain criteria in order to help her students understand isolated words or ones which are found in the text. The findings reveal that Ustazah Nuraini has applied and selected the words based on several considerations and criteria. For more detailed explanations, the findings are reported based on the categories discussed in the earlier section. There are: i) priority; ii) frequency; iii) teach ability; iv) coverage; and v) familiarity.

The results as shown in Table 1 below of the interviews manifest how the related teacher provided her strategies and practices in selecting words for her Arabic Language class among lower secondary students.

The data are evidence of the priority criterion selected by Ustazah Nuraini in teaching vocabulary to her students. The selected words belong to the main vocabulary, basic vocabulary, essential vocabulary (for examination), new vocabulary, difficult vocabulary (abstract), vocabulary based on particular themes, vocabulary based on lesson topics, and vocabulary based on verbal communication in or outside school. Besides she also chose the frequency criterion as the words are often repeated in the text, real life, based on her students' experiences and even in the examination.

It is also evident that Ustazah Nuraini chose familiar words to be taught as she referred to vocabulary normally used in students' daily activities. For the all-encompassing criterion, she was also seen emphasizing words which are widely used in various contexts based on topics or outside the topics such as the usage of "lughatulfasli” for communication in school and inside the class. Finally, Ustazah Nuraini also used concrete words which were easy for her students to understand and words with meanings easy to be explained through pointing 
Table 1. Extract from interview transcriptions.

\begin{tabular}{|c|c|}
\hline Interview & Description \\
\hline "It's important the 'feel' or 'isim'... I feel it all important" & The criterion priority: \\
\hline "Words normally asked in the examination" & Important words: nouns and verbs \\
\hline "I will ask my students to produce new words or phrases which they & i) Examination words \\
\hline don't know or difficult" & ii) New words \\
\hline "Vocabulary which they students are not familiar with (rarely see)" & iii) Difficult words \\
\hline "I will list down new words based on themes I select" & iv) Not familiar \\
\hline "I will choose based on the topic I teach that day" & v) Words based on themes \\
\hline \multirow{2}{*}{$\begin{array}{l}\text { "Teaching vocabulary outside the textbook because I think those words } \\
\text { are used by students in their daily lives" }\end{array}$} & vi) Words based on topics \\
\hline & vii) Vocabulary based on verbal communication in or outside school \\
\hline \multirow{7}{*}{$\begin{array}{l}\text { "Words which students normally encounter" } \\
\text { "My selection of vocabulary is the one that is used very often or seen } \\
\text { often by the students when learning Arabic from the textbook" } \\
\text { "Words that are normally repeated" } \\
\text { "He once encountered the word while reading a magazine or book or } \\
\text { when he was in a primary school" } \\
\text { "Words normally asked in the examination" }\end{array}$} & The criterion frequency: \\
\hline & \\
\hline & $\begin{array}{l}\text { often: } \\
\text { i) In the life of a student }\end{array}$ \\
\hline & $\begin{array}{l}\text { 1) In the life of a student } \\
\text { ii) In learning texts }\end{array}$ \\
\hline & iii) Repeated words \\
\hline & iv) Based on students' experiences learning such vocabulary \\
\hline & v) In the examination \\
\hline \multirow{4}{*}{$\begin{array}{l}\text { "Words which the students always encounter" } \\
\text { "Why did I choose this...because I think it's close to the students" } \\
\text { "For my form one students, I will start with words related to themselves" } \\
\text { "Words which are normally repeated" }\end{array}$} & The criterion familiarity. Among the criteria are words which are: \\
\hline & i) Familiar or close to the students \\
\hline & ii) Often encountered \\
\hline & iv) Often repeated in daily life \\
\hline $\begin{array}{l}\text { "I first introduce 'lughatulfasl' (common daily phases in classroom or at } \\
\text { school) used by the students" } \\
\text { "Teach words outside the textbook" }\end{array}$ & $\begin{array}{l}\text { The criterion all-encompassing. Such vocabulary portrays: } \\
\text { i) varieties based on topics or outside the topics such as the usage of } \\
\text { "lughatulfasli" for communication with the teacher in school and } \\
\text { inside the class. }\end{array}$ \\
\hline \multirow{8}{*}{$\begin{array}{l}\text { "If we're in class, there are many examples of "visible objects like babun } \\
\text { (door), tolibun (student), muallimun (teacher)... then things which } \\
\text { students can see... yes...'maujud' objects" } \\
\text { "Give them words or phrases which they understand" } \\
\text { "Visible objects which the students can see, touch, feel around them" } \\
\text { "I will choose the word... it; s not difficult" } \\
\text { "The new words I will select based on suitability with my form one } \\
\text { students" } \\
\text { "I ensure in my teaching and learning, students can master ten new } \\
\text { words" }\end{array}$} & \\
\hline & The criterion easy to learn. Such vocabulary may: \\
\hline & i) Refer to concrete meanings \\
\hline & ii) Have meanings easy to be explained \\
\hline & iii) Contain obvious meanings \\
\hline & iv) Be made up of easy words \\
\hline & v) Be appropriate with the students' level \\
\hline & \\
\hline
\end{tabular}

to real life objects nearby. Such vocabulary may also refer to concrete, easy-to-understand meanings appropriate with the students' level. Table 2 Notes based on Ustazah Nuraini's classroom observation.

Data from document analysis revealed Ustazah Nuraini's way of teaching vocabulary to be based on a social theme (theme-based criterion) with the topic being related to students' lives (based on students' experience and environment) and words taught for language practice (specific requirement). There are 10 words stated in the learning objectives (based on suitability with students).

Data from the field notes revealed that Ustazah Nuraini's way of teaching vocabulary was based on a social theme (theme-based criterion) which included students' lives (experience and environment), real objects, familiar situations, new words and words for general situation. Below are words related to the theme for a lesson on birthday party.

Based on Tables 1-5, the findings reveal that there are five criteria of word selection identified in the respondent's teaching of her form one class. The five criteria are: i) priority; ii) frequency; iii) teach ability; iv) coverage; and v) familiarity. This indicates the need for such consideration when teaching a lower secondary level in line with the learning objectives.

According to Nation (2013), word selection process should be conducted prior to the teaching and learning because lesson emphasis and focus may differ depending on the objectives. Silverman \& Hartranft (2015) also concede that all language teachers must pay attention to the vocabulary selected for teaching because students are required to learn a vast collection of words. Hence it is wise for teachers to select vocabulary based on 
Table 2. Extract from introduction—“the taa'ruf at birthday party” observation 1/2 April 2015.

\begin{tabular}{|c|c|}
\hline Observation in Form One Arif Classroom & Description \\
\hline $\begin{array}{l}\text { Teacher mentions the topic التعار ففيعيدالميلاد and asks the students to } \\
\text { repeat the phrase. All students repeat the phrase in unison: } \\
\text { التعار ففيعيدالميلاد }\end{array}$ & $\begin{array}{l}\text { Criteria for vocabulary selection: } \\
\text { i) Based on students' real lives } \\
\text { ii) New, essential vocabulary related to topic } \\
\text { iii) Related to Malay word: } \\
\text { تعارف (taa'ruf) }\end{array}$ \\
\hline 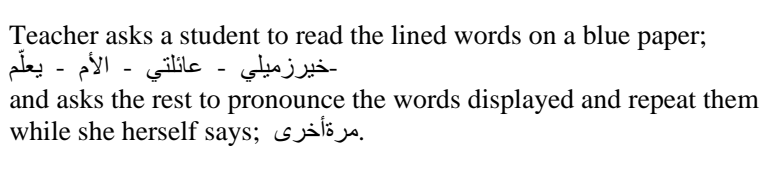 & 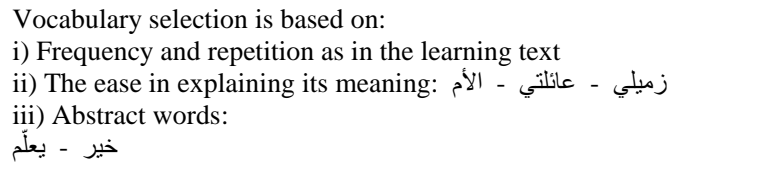 \\
\hline 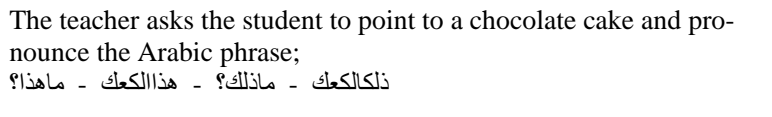 & $\begin{array}{l}\text { Word selected is based on: } \\
\text { i) A situation closely related to students' lives but rarely used; الكعك }\end{array}$ \\
\hline  & 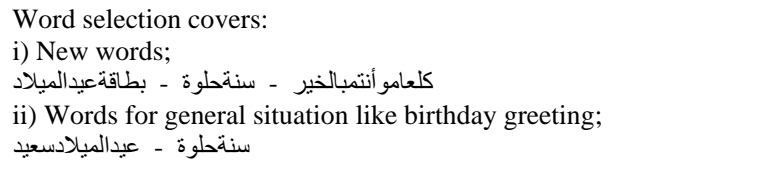 \\
\hline
\end{tabular}

Table 3. Extract from document analysis transcriptions taken from a teaching record book.

\begin{tabular}{ll}
\hline Document & Description \\
\hline & i) Learning aspect (social): Theme-based criterion \\
& ii) Related theme “Self-introduction paving way for friendship”: Theme-based \\
criterion
\end{tabular}

Table 4. Extract from the researcher's field note book.

\begin{tabular}{|c|c|}
\hline Field notes & Description \\
\hline 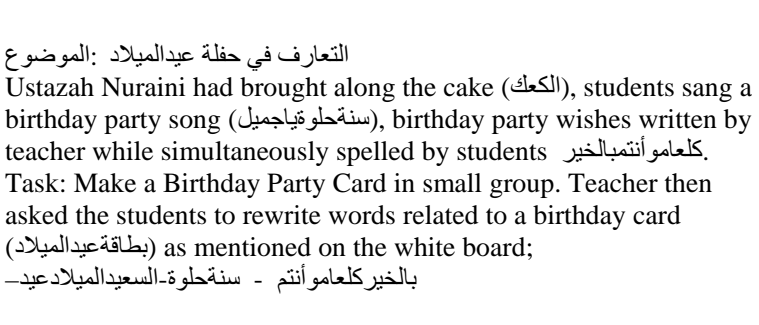 & 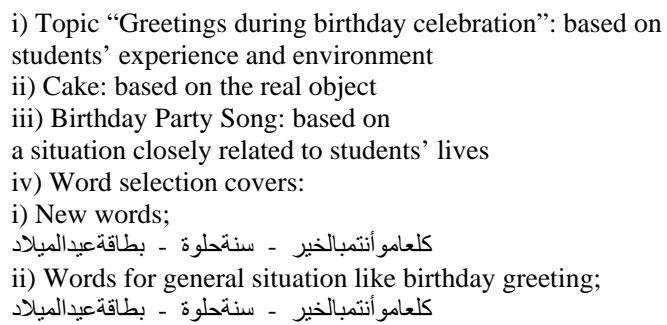 \\
\hline
\end{tabular}

guidelines and criteria proposed by the language experts (Tacimah, 1989; Abd Bari, 2011; Nation 2013). This is because vocabulary selection based on randomness and assumption will not contribute to effective mastery of the words (Chik, 1994) which then can lead to difficulty for students to understand and recall the words (Mohamad, 2015).

\section{Conclusion}

Vocabulary selection is a complementary element to the teaching and learning of a language hence it is one process which requires careful consideration and attention from a language teacher. In the context of teaching, Arabic as a second language in Malaysia, it is no difference as vocabulary selection can guide the teachers in tailoring their teaching techniques to suit the students' level hence helping them master the Arabic vocabulary. The 
Table 5. Triangulation of data from the single case study based on the notes obtained.

\begin{tabular}{|c|c|c|c|c|c|}
\hline Criteria & Category & & & & \\
\hline Interview & Priority & Frequency & Familiarity & Coverage & $\begin{array}{l}\text { Teach } \\
\text { Ability }\end{array}$ \\
\hline Important words: nouns and verbs & / & & & & \\
\hline Examination words & / & & & & \\
\hline New words & / & & & & \\
\hline Difficult words & / & & & & \\
\hline Not familiar & / & & & & \\
\hline Words based on themes & 1 & & & & \\
\hline Words based on topics & / & & & & \\
\hline Vocabulary based on verbal communication in or outside school & I & & & / & \\
\hline Repeated in the life of a student & & / & & & \\
\hline Repeated in learning texts & & l & & & \\
\hline Repeated words & & / & & & \\
\hline Based on students' experiences learning such vocabulary & & / & & & \\
\hline Repeated in the examination & & / & & & \\
\hline familiar or close to the students & & & / & & \\
\hline Often encountered & & & / & & \\
\hline Related to topics familiar to students & & & / & & \\
\hline Often repeated in daily life & & & / & & \\
\hline $\begin{array}{l}\text { Varieties based on topics or outside the topics such as the usage of } \\
\text { "Iughatulfasli" for communication with the teacher in school and } \\
\text { inside the class. }\end{array}$ & & & & / & \\
\hline Refer to concrete meanings & & & & & I \\
\hline Have meanings easy to be explained & & & & & / \\
\hline Contain obvious meanings & & & & & / \\
\hline Be made up of easy words & & & & & / \\
\hline Be appropriate with the students' level & & & & & / \\
\hline Be limited in number & & & & & / \\
\hline $\begin{array}{l}\text { Observation } \\
\text { Based on students' real lives }\end{array}$ & & & I & & \\
\hline New, essential vocabulary related to topic & / & & & & \\
\hline Related to Malay word: تعارف (taa'ruf) & & & & & / \\
\hline Frequency and repetition as in the learning text & & / & & & \\
\hline $\begin{array}{l}\text { The ease in explaining its meaning: } \\
\text { زميلي - عائلتي - الام }\end{array}$ & & & & & / \\
\hline خير - يعلَّم: Abstract words & & & & & / \\
\hline الكعك ; situation closely related to students' lives but rarely used & & & / & & \\
\hline Sلع Nords; ملعوأنتمبالخير - حلوقسنة - الميلادعيد - بطاقة & / & & & & \\
\hline $\begin{array}{l}\text { Words for general situation like birthday greeting; } \\
\text { سنةحلوة - عيدالميلادعيد }\end{array}$ & & & I & & \\
\hline $\begin{array}{l}\text { Document } \\
\text { Learning aspect (social): Theme-based criterion }\end{array}$ & 1 & & & & \\
\hline
\end{tabular}




\section{Continued}

Related theme "Self-introduction paving way for friendship": Theme-based criterion

Topic “Greetings during birthday celebration”: based on students' experience and environment

Objectives:

-to read and understand hiwar text and comprehension)

-to pronounce 10 new words and understand their synonyms and antonyms

-to carry out conversation based on given words

\section{Field Note}

A situation closely related to students' lives and used the real object; الكعك

Topic “Greetings during birthday celebration”: based on students” experience and environment

New words; كلعامو أنتمبالخير - حلوةسنة - الميلادعيد- بطاقة

/

(1)

Words for general situation like birthday greeting; سنةحلوة - عيدالميلادسعيد

findings from the study may provide guidelines to Arabic language teachers specifically in regard to choosing vocabulary to be taught in class. Besides the results may also have an impact on the Arabic language syllabus and textbook for lower secondary level especially in vocabulary selection. This is to help Arabic language teachers carry out strategies in teaching vocabulary in line with learning objectives and learner variability.

\section{References}

Abd Bari, S. M. (2011). Strategies of Teaching Vocabulary. Amman: Darul Masirah li Nasyri wa Tauzi.

Abdullah, N., \& Sivaganga, S. (2010). Text Appeal: The Link between Familiarity and Learners' Response. In N. A. Mahir, N. S. M. Saad, \& H. H. M. Sidek (Eds.), Essays on ESL Reading and Writing (pp. 69-92). Nilai: Islamics Science University of Malaysia (USIM) Publisher.

Benjamin, A., \& Crow, J. T. (2010). Vocabulary at the Center. Larchmont: Eye on Education.

Biemiller, A. (2010). Words Worth Teaching: Closing the Vocabulary Gap. In E. H. Hiebert, \& M. L. Kamil (Eds.), Teaching and Learning Vocabulary: Bringing Reseach into Practice (pp. 223-242). NJ: Lawrence Erlbaum Associates.

Chik, A. R. (1994). Mā̄yir al-Tahakkum fi al-Alfaz fi T“alim al-Arabiyyah li al-Mujtama”t al-Islamiyyah fi Janub Sharq Asiya. Egypt: University Iskandariah.

Chik, A. R. A. (2004). Pendekatan pengajaran berasaskan kata serapan bahasa Melayu untuk meningkatkan pemahaman perbendaharaan kata bahasa Arab Tinggi. Bangi: Universiti Kebangsaan Malaysia.

Creswell, J. W. (2014). Research Design: Qualitative, Quantitative and Mixed Methods Approaches. Thousand Oaks: Sage Publications, Inc.

Curriculum Development Department (2007). Sukatan Pelajaran Bahasa Arab Tingkatan Satu. Putrajaya: Ministry of Education Malaysia.

Ghani, K. A. (2011). Kebolehbacaan Buku Teks Bahasa Arab Tinggi Berasaskan Ujian Kloz Dalam Kalangan Pelajar Di SMKA. GEMA Online ${ }^{\circledR}$ Journal of Language Studies, 11, 53-66.

Hussin, Z. (2011). Perbandingan Pengajaran dan Pembelajaran Perbendaharaan Kata Bahasa Arab mengikut Kluster Semantik dan Kluster Bebas. Bangi: Universiti Kebangsaan Malaysia.

Kadir, A. K. A. (2011). Maurid al-Salikin; Kamus Sinonim Antonim Bahasa Arab. Kajang: One Touch Creative Sdn Bhd.

Merriam, S. B. (2009). Qualitative Research: A Guide to Design and Implementation (The Jossey Bass Higher and Adult Education Series) (Volume 2). E-Published.

Mezah, C. R., \& Mohamad, N. (2013). Kosa Kata Teori dan Aplikasi. Serdang: Universiti Putra Malaysia Publisher.

Mohamad, A. H. (2015). Konsep Pemilihan Kosa Kata dalam Pembelajaran Bahasa: Satu Kajian ke atas Buku Teks Bahasa Arab Tahun 1. In Prosiding Persidangan Kebangsaan Bahasa Arab (NCAL) (pp. 211-217). Bandar Baru Bangi: Aras Mega Sdn Bhd..

Mohamad, N. (2001). Masalah ingatan di kalangan pelajar dewasa bahasa Arab UiTM. Kuala Lumpur: University of Malaya. 
Nagy, W., \& Anderson, R. (1984). How Many Words Are There in Printed School English. Reading Research Quarterly, 19, 304-330. http://dx.doi.org/10.2307/747823

Nation, I., \& Beglar, D. (2007). A Vocabulary Size Test. The Language Teacher, 31, 9-13.

Nation, I. S. P. (2013). Learning Vocabulary in Another Language. Cambridge: Cambridge University Press.

Rahimi, N. M., Husin, Z., \& Normezah, W. (2014). Pembelajaran kosa kata bahasa Arab secara aturan kluster semantic dan aturan kluster bebas. Jurnal Teknologi, 67, 33-38.

Ramli, M. K. H., \& Mohamad, A. H. (2014). Tahap kekerapan dan kepadatan kosa kata buku teks bahasa Arab sekolah rendah. $J P B U, 7,16-28$.

Razak, Z. R. A. (2014). Word Usage Variations in Arabic Newspapers: A Corpus Investigation. GEMA Online ${ }^{\circledR}$ Journal of Language Studies, 14, 29-43. http://dx.doi.org/10.17576/GEMA-2014-1402-03

Samah, R., Hamid, M. F. A., Sha’ari, S. H., \& Sha’ari, S. H. (2013). Aktiviti pengajaran kemahiran bertutur bahasa Arab dalam kalangan jurulatih debat. GEMA Online ${ }^{\circledR}$ Journal of Language Studies, 13, 99-116.

Seman, M., Abdullah, M. A., Othman, R., \& Hasmadi (2009). Al-Lughatul Al-Arabiyyah Li-Sanah Al-Ula. Kajang: Sinar Jimet Sdn Berhad.

Silverman, R. D., \& Hartranft, A. M. (2015). Developing Vocabulary and Oral Language in Young Children. New York: The Guilford Press.

Tacimah, R. A. (1989). Al Usus al-`Ammah li Manahij Ta’lim al-Lughah al-cArabiyyah. Cairo: Darul Fikri al-Arabi.

Tacimah, R. A. (2001). Manahij Tadris al-Lughah al-Arabiyyan al-Ta‘lim al-Asasi. Cairo: Darul Fikr al-Arabiy Press.

Yin, R. K. (2011). Qualitative Research from Start to Finish. New York: Guilford. 